\title{
HERITABILITY OF URINE AND PLASMA AMYLASE ACTIVITY
}

\author{
K.S. PARK \\ Institute of Brain Research, University of Tokyo School of Medicine
}

\begin{abstract}
Summary Urine amylase activity was measured in 142 boys and girls including unrelated twin individuals, aged 12-16 years. Statistical analysis revealed different distribution in the group with positive protein or blood reaction. Log distribution in a homogeneous sample population was unimodal with a skewness $\left(\sqrt{\beta_{1}}=-0.6493\right)$ and kurtosis $\left(\beta_{2}=3.4917\right)$. Intraclass correlation coefficients of overall activities were $0.6696(\mathrm{p}<0.001)$ in MZ twins (50 pairs) and -0.1299(n.s.) in DZ twins (22 pairs). In the rate of isozyme activity, correlation was nonsignificant.

Plasma of 36 twin pairs aged 13 to 15 years were similarly examined. Log distribution of overall activity was unimodal with a skewness $\left(\sqrt{\beta_{1}}=\right.$ $0.2321)$ and kurtosis $\left(\beta_{2}=-0.7416\right)$. Intraclass correlation coefficients of overall activity were $0.8413(\mathrm{p}<0.001)$ in $\mathrm{MZ}$ twins (29 pairs) and 0.3689 (n.s.) in DZ twins (7 pairs). Intraclass correlation of plasma isozyme activity rate was $0.5490(\mathrm{p}<0.01)$ in $\mathrm{MZ}$ twins, but not significant in $\mathrm{DZ}$ twins.

Parent-offspring correlation of plasma overall amylase activity was $0.2848(\mathrm{p}<0.05)$ and its mid-parent-offspring correlation was 0.3727 $(p<0.05)$. Heritability was 0.5298 from parent-offspring regression and 0.4408 from mid-parent-offspring regression.
\end{abstract}

\section{INTRODUCTION}

Amylase activity of human body fluids is known to be influenced by such disease conditions as chronic and acute pancreatitis. On the other hand, amylase activity is also known to vary among individuals. The present study aims at clarifying genetic control of overall amylase activity and the rate of isozyme activity in urine and plasma in healthy subjects.

Human amylase is separated into two isozymes, Amy 1 and Amy 2, by electrophoresis (Aw, 1966; Nørby, 1964; Götz et al., 1968; Vaciková and Blochová, 1969; Muss and Vnenchak, 1964; Berk et al., 1966; Wolf and Taylor, 1967) and by Sephadex chromatography (Fridhandler et al., 1972). Amy 1 has been regarded to have salivary gland origin, and Amy 2 pancreas origin, but the isozymes can also be found in serum 
and urine, as well as in other body fluids such as duodenal aspirate, tear fluid and amniotic fluid. Variants of the two isozymes, codominant to normal isozymes, were reported (Kamarýt and Laxová 1965, 1966; Wolf et al., 1971; Merritt et al., 1973), and gene loci of the two isozymes are both assigned to chromosome 1 (Kamarýt et al., 1971; Merritt et al., 1972).

The present study consists of five parts. First and second are the studies on the distributions among the general population of overall amylase activity and the rate of isozyme activity in urine and plasma, respectively. Third and fourth are on twin correlations of urine and plasma overall amylase activity and the rate of isozyme activity. Fifth is an estimation of heritability of overall plasma amylase activity and the rate of isozyme activity using parent-offspring regression in twin families.

\section{MATERIALS AND METHODS}

Subjects. The initial sample of general population subjected for the study of urine amylase activity consists of 80 twin individuals and 62 singletons, totaling 142 unrelated subjects, aged 12-16 years. For the study of plasma amylase activity 36 twin individuals aged 13-15 years were regarded to constitute a sample of the general population. All these subjects are students at Junior and Senior High Schools attached to the Faculty of Education, University of Tokyo and their grades are 1 to 3 in Junior High, and 1 in Senior High. Twins subjected to the correlations and heritability studies below are also students at the above school. For the study of twin correlations of urine overall amylase activity 50 monozygotic (MZ) and 22 dizygotic (DZ) twin pairs aged 12-16 years were examined. All urine specimens were collected at either of $9: 20,10: 20,11: 20 \mathrm{a} . \mathrm{m}$. or $0: 20 \mathrm{p} . \mathrm{m}$. For the study of twin correlations of overall plasma amylase activity $29 \mathrm{MZ}$ and $7 \mathrm{DZ}$ twin pairs were subjected to the study, and heparinized blood was taken on the same day within $2 \mathrm{hr}$. For the heritability study heparinized blood from another sample of twins (17 males and 21 females from 19 pairs, aged 11 and 12 years) and their parents was taken on the same day within $3 \mathrm{hr}$ for the examination of overall plasma amylase activity. Blood was similarly taken from an additional sample of twins (18 males and 16 females from 17 pairs, aged 11 and 12 years) and their parents for estimating heritability of the rate of isozyme activity in plasma.

At the school subjects were not selected at the enrollment, except for area of residence and academic achievements. They were normal and in good health. Zygosity of twins was diagnosed by two methods of Inouye (1956, 1962). The latter method employs $\mathrm{ABO}, \mathrm{MN}$ blood groups, $\mathrm{ABH}$ secretor, finger prints, earwax type, PTC, and mid-digital-hair. The former method employs, besides the above traits, other anthropological traits and genetic markers.

By electrophoresis it is confirmed that no variant is included in the present subjects.

Measurement of overall amylase activity. Overall amylase activity of urine and 
plasma was determined by using Amylase Test Daiichi (Lot No. 007RFX, Daiichi Pure Chemicals Co., Tokyo, Japan). The procedure was as follows: $0.1 \mathrm{ml}$ urine or plasma and $4 \mathrm{ml}$ of distilled water were preincubated at $37^{\circ} \mathrm{C}$ for $5 \mathrm{~min}$. One starch tablet was added to each tube. After rigorous shaking with a touch-mixer for $10 \mathrm{sec}$, tubes were incubated at $37^{\circ} \mathrm{C}$ for $30 \mathrm{~min}$ for plasma, and $15 \mathrm{~min}$ for urine. A blank containing distilled water instead of the specimens was treated in the same same way. The reaction was stopped by adding $1 \mathrm{ml}$ of $0.5 \mathrm{~N} \mathrm{NaOH}$; then the mixture was read at $620 \mathrm{~nm}$ on a HITACHI 124 Spectrophotometer comparing to the rate of the blank. Readings were converted into Somogyi units.

Electrophoresis. A quantitative analysis of Amy 1 and Amy 2 isozymes in urine and plasma was performed after electrophoresis. Electrophoresis using 5\% polyacrylamide thin layer gel $(1 \mathrm{~mm})$ was carried out at $1 \mathrm{~mA}$ per $\mathrm{cm}$ for $3 \mathrm{hr}$ at $4^{\circ} \mathrm{C}$ with Tris- $\mathrm{HCl}$ buffer for gel and Boric acid-NaOH buffer for electrode. The gel was incubated at $37^{\circ} \mathrm{C}$ in $1 \%$ soluble starch solution containing $0.2 \%$ sodium chloride for $3 \mathrm{hr}$. After incubation the gel was immersed in $5 \%$ acetic acid for $3 \mathrm{~min}$, and developed with KI-iodine solution. Densitometry was done at $620 \mathrm{~nm}$ on Densitron Model PAN II JOOKOO and areas corresponding to the major Amy 1 and Amy 2 isozyme bands were measured on the recording paper. In the following chapters the area of the major Amy 1 isozyme band is designated S, and that of the major Amy 2 isozyme band is $P$.

\section{RESULTS}

1. Overall urine amylase activity and the rate of isozyme activity in the general population

Preliminary examination of the daily fuctuation of overall urine amylase activity. It is known that urine amylase activity varies diurnally. Therefore, a preliminary test was performed on 4 healthy women, and a regression equation ( $Y=675-92 X$, $X=1,2,3$ ) was obtained. The regression coefficient was tested by the conventional F-test after Rao (1952), and the equation was utilized for the correction of amylase activity to that measured at a fixed time $(0: 20$ p.m. $)$.

Effects of urine protein, blood reaction, $p H$ and glucose on overall urine amylase activity. Hema-combistix (Ames Division, Miles-Sankyo Co.) were used to determine the level of urinary protein levels $(-, \pm: 5-20 \mathrm{mg} / 100 \mathrm{ml},+: 30 \mathrm{mg} / 100 \mathrm{ml}$, $++: 100 \mathrm{mg} / 100 \mathrm{ml}$ ), presence of blood (positive at low, medium, high levels), $\mathrm{pH}$ $(5,6,7,8)$ and glucose levels $(-, \pm: 0.25 \%,+: 0.5 \%,++:$ more than $0.5 \%)$.

There was no individual with glucose positive urine.

As to the overall amylase activity variances of protein-positive ( + or more) urine $(\mathrm{N}=15)$ and protein negative urine $(\mathrm{N}=127)$ were significantly different $(F=2.744, p<0.05)$, and the mean was higher in the former than in the latter. After having excluded protein positive urine specimens the effect of blood reaction was examined. 
Variance of blood reaction positive urine $(\mathrm{N}=8)$ and blood reaction negative urine $(\mathrm{N}=119)$ were significantly different $(\mathrm{F}=3.715, \mathrm{p}<0.01)$. The mean was higher in the latter than in the former. The effect of $\mathrm{pH}$ was then examined, after having excluded the blood reaction positive urine specimens.

Variance of the two groups, $\mathrm{pH} 7$ or over $(\mathrm{N}=9)$ and 6 or under $(\mathrm{N}=110)$ were not significantly different. Group of $\mathrm{pH} 6$ or under indicated a higher mean than the group of $\mathrm{pH} 7$ or over, but the difference was not significant.

Effect of time of urine collection on overall urine amylase activity. Next the protein-negative and blood reaction negative urines were analyzed in relation to the time of urine collection. As mentioned above, the activity values subjected to this analysis were those already corrected for sampling time. The amylase activity of the urine collected at different sampling times indicated no statistically significant differences. As to the effect of age, the amylase activity of the urine taken from 1 st grade students of Junior High School (aged 12 and 13 years) indicated a significantly different variance from the rest of the classes, and they were excluded from the sample.

Distribution of overall urine amylase activity. The number of remaining subjects after the above exclusions (protein-positive, blood reaction positive and students of Junior High School grade 1) is 67 and constituted the final sample of the general population. A significant regression of activity on school class was indicated, with a tendency of increase of amylase activity with age, ranging from 13 to 16 years. Sex difference was not significant.

The logarithmic distribution of overall urine amylase activity among the final samples of the general population was unimodal with a skewness $\left(\sqrt{\beta_{1}}=-0.6493\right)$ and a kurtosis $\left(\beta_{2}=3.4917\right)$. The mean was $360.6 \pm 197.7$ Somogyi unit.

Distribution of the rate of isozyme activity in urine. As to variances and means. of the rate of isozyme activity ( $\mathrm{S}$ or $\mathrm{P} / \mathrm{S}+\mathrm{P}$ ) of urine there was no significant difference between protein positive and negative specimens, between blood reaction positive and negative specimens or between specimens with $\mathrm{pH} 6$ or under and 7 or over. No significant difference was also indicated among the specimens with different time of urine collection or between sexes, or among school classes. Distribution of the rate of Amy 1 activity (S) or Amy 2 activity (P) to $\mathrm{S}+\mathrm{P}$ activity of urine after angular transformation $\left(\operatorname{Sin}^{-1} \sqrt{\frac{\mathrm{S}}{\mathrm{S}+\mathrm{P}}}\right.$ or $\left.\operatorname{Sin}^{-1} \sqrt{\frac{\mathrm{P}}{\mathrm{S}+\mathrm{P}}}\right)$ are presented in Fig. 1. The mean were $43.2865 \pm 7.8592\left(\operatorname{Sin}^{-1} \sqrt{\frac{\mathrm{S}}{\mathrm{S}+\mathrm{P}}}\right)$ and $46.5735 \pm 7.8349\left(\operatorname{Sin}^{-1} \sqrt{\frac{\mathrm{P}}{\mathrm{S}+\mathrm{P}}}\right)$.

2. Overall plasma amylase activity and the rate of isozyme activity in the general population

The Number of subjects is 36 . Sex difference was not indicated in overall amylase activity or the rate of isozyme activity of plasma. Logarithmic distribution of overall activity was also unimodal with a skewness $\left(\sqrt{\beta_{1}}=0.2321\right)$ and a kurtosis $\left(\beta_{2}=-0.7416\right)$. The mean is $123.0 \pm 31.0$ Somogyi unit. For isozyme activity rates, 

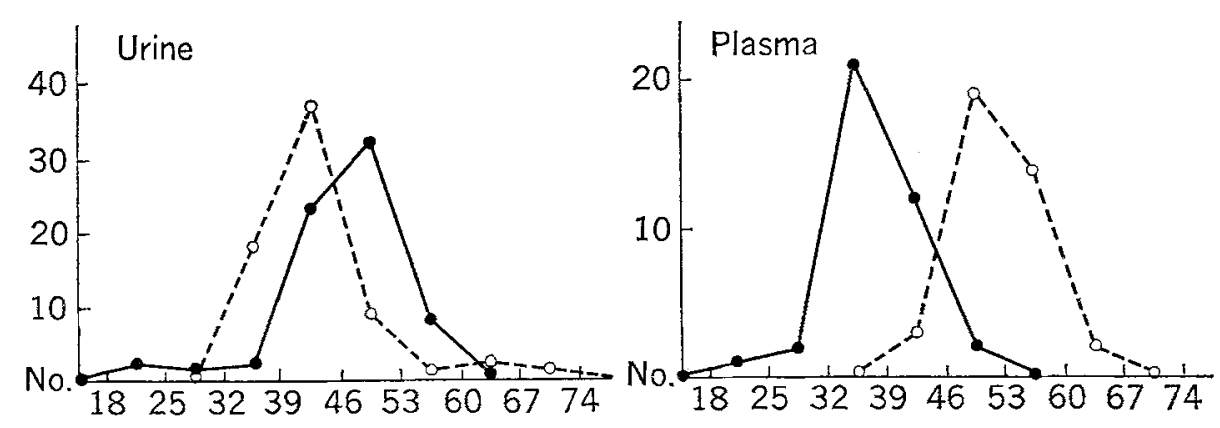

Fig. 1. Distributions of the rates of Amy $1\left(\operatorname{Sin}^{-1} \sqrt{\frac{\mathrm{S}}{\overline{\mathrm{S}}+\overline{\mathrm{P}}}}\right.$, dotted lines) and Amy 2

$\left(\operatorname{Sin}^{-1} \sqrt{\frac{\mathrm{P}}{\mathrm{S}+\mathrm{P}}}\right.$, solid lines) activity in urine and plasma.

Table 1. Intraclass correlations(r) of overall amylase activity and the rate of isozyme activity in urine and plasma.

\begin{tabular}{|c|c|c|c|c|c|c|}
\hline & \multicolumn{2}{|c|}{ Urine } & $\begin{array}{c}\text { Difference }{ }^{\dagger} \\
\text { between }\end{array}$ & \multicolumn{2}{|c|}{ Pasma } & \multirow{2}{*}{$\begin{array}{c}\begin{array}{c}\text { Difference } \\
\text { between }\end{array} \\
\mathrm{MZ} \& \mathrm{DZ}\end{array}$} \\
\hline & $\mathrm{MZ}$ & $\mathrm{DZ}$ & $\mathrm{MZ} \& \mathrm{DZ}$ & $\mathrm{MZ}$ & $\mathrm{DZ}$ & \\
\hline Overall activity & $\begin{array}{c}0.6696^{* *} \\
\mathrm{n}=50\end{array}$ & $\begin{array}{c}-0.1299 \\
n=22\end{array}$ & $*$ & $\begin{array}{c}0.8413^{* *} \\
n=29\end{array}$ & $\begin{array}{c}0.3689 \\
n=7\end{array}$ & $*$ \\
\hline $\operatorname{Sin}^{-1} \sqrt{\frac{S}{S+P}}$ & $\begin{array}{c}0.2317 \\
\mathrm{n}=41\end{array}$ & $\begin{array}{c}0.5445 \\
\mathrm{n}=13\end{array}$ & & $\begin{array}{r}0.5490^{*} \\
\mathrm{n}=29\end{array}$ & $\begin{array}{l}0.4226 \\
n=7\end{array}$ & \\
\hline $\begin{array}{l}\text { * Significant } \\
\text { ** Significant }\end{array}$ & ae $0.01 \mathrm{le}$ & $\begin{array}{l}\text { of probat } \\
1 \text { of proba }\end{array}$ & $\begin{array}{l}y . \\
\text { ity. }\end{array}$ & $\frac{z_{1}-z_{2}}{\frac{1}{3}+\frac{1}{N}}$ & - & $=1 / 2 \log \frac{1+r}{1-r}$ \\
\hline
\end{tabular}

the result is also shown in Fig. 1. The mean were $52.4390 \pm 4.7036\left(\operatorname{Sin}^{-1} \sqrt{\frac{\mathrm{S}}{\mathrm{S}+\mathrm{P}}}\right)$ and $37.5610 \pm 4.7036\left(\operatorname{Sin}^{-1} \sqrt{\frac{\mathrm{P}}{\mathrm{S}+\mathrm{P}}}\right)$.

A significantly lower pancreatic isozyme activity rate was seen in plasma compared to urine $(t=5.7805, p<0.001)$.

3. Twin correlations of overall urine amylase activity and the rate of isozyme activity.

Subjects were selected in accordance with the criteria for the final sample of general population subjected for the study of overall urine amylase activity. Intraclass correlation coefficients of overall amylase activity and the rate of Amy 1 activity (S) to $\mathrm{S}+\mathrm{P}$ activity of urine after angular transformation are shown in Table 1. As to overall activity a higher intraclass correlation coefficient was indicated in $\mathrm{MZ}$ twins than DZ twins. But in the rate of isozyme activity the correlation coefficient is nonsignificant, and the difference between $\mathrm{MZ}$ and $\mathrm{DZ}$ twins is not clear. 
Table 2. Parent-child and husband wife correlations for overall plasma amylase activity and the rate of isozyme activity.

\begin{tabular}{lcccc} 
& $\begin{array}{l}\text { Overall } \\
\text { activity }\end{array}$ & No. & $\operatorname{Sin}^{-1} \sqrt{\frac{\mathrm{S}}{\mathrm{S}+\mathrm{P}}}$ & No. \\
\hline father-son & $0.4761^{*}$ & 17 & $0.4633^{*}$ & 18 \\
father-daughter & $0.4637^{*}$ & 17 & $-0.4538^{*}$ & 16 \\
mother-son & $0.4461^{*}$ & 16 & $0.8681^{* * * *}$ & 18 \\
mother-daughter & -0.1686 & 20 & 0.2963 & 16 \\
parent-offspring & $0.2848^{* *}$ & 70 & $0.3003^{* * *}$ & 68 \\
mid-parent-children & $0.3727^{* *}$ & 32 & $0.3848^{* * *}$ & 34 \\
husband-wife & 0.0694 & 16 & 0.2813 & 17 \\
\hline
\end{tabular}

$* \mathrm{p}<0.1, \quad * * \mathrm{p}<0.05, \quad * * * \mathrm{p}<0.02, \quad * * * * \mathrm{p}<0.001$.

4. Twin correlations of overall plasma amylase activity and the rate of isozyme activity Intraclass correlation coefficients of overall activity and the rate of isozyme activity of plasma are also shown in Table 1 . Unlike urine, the findings in $\mathrm{MZ}$ twins indicated significant and higher correlation coefficients than those of $\mathrm{DZ}$ twins in these comparisons, but $z$ test on the difference between $\mathrm{MZ}$ and $\mathrm{DZ}$ twins was significant only in overall activity.

5. Heritability of overall plasma amylase activity and the rate of isozyme activity

Correlations of overall plasma amylase activity and the rate of isozyme activity between family members are shown in Table 2. A low mother-daughter correlation is indicated. Heritability $\left(\mathrm{h}^{2}\right)$ of overall plasma amylase activity was estimated at 0.5298 from parent-offspring regression and 0.4408 from mid-parent-offspring regression. For the rate of isozyme activity $\left(\operatorname{Sin}^{-1} \sqrt{\frac{\mathrm{S}}{\mathrm{S}+\mathrm{P}}}\right), \mathrm{h}^{2}$ was 0.7525 from parentoffspring regression and 0.6163 from mid-parent-offspring regression.

\section{DISCUSSION}

McCorkle and Goldman (1942) reported that amylase activity of serum of a normal person was usually very nearly at the same level regardless of fasting, feeding, kind of foods, time of day and exercise. Van Riet and Hoeke (1968) reported that in 10 normal subjects urinary excretion of amylase during a 24-hour period took an unpredictably irregular course, showing no systematic diurnal peak, nor a nocturnal dip. In the present preliminary study, urinary amylase activity differs with respect to the time of day extending over two hours. In order to examine the validity of this finding, the regression of activity on the time of urine sampling was taken into account in order to convert the activity values in the general population. The converted value no longer indicated significant daily fluctuation.

Amylase activity of protein-positive urine was higher than protein-negative urine. 
The result is in accordance with O'Donnell and McGeeney (1974) who found that amylase hydrolysis of the insoluble starch substrate (PHADEBAS) requires addition of protein for optimal activity. The same finding was reported by other investigators (Irie et al., 1972; Hall et al., 1970: Searcy et al., 1964; Ujihira et al., 1965).

Reif and Nabseth (1962) reported that blood reaction negative urine indicated higher activity than blood reaction positive urine, which is in agreement with the present result.

Amylase activity has a broad range of $\mathrm{pH}$ between 3.8 and 9.4, with a optimum at pH 6.9 (Bernfeld 1955; Walker and Hope 1963). O'Donnell and McGeeney (1974) reported that at $\mathrm{pH} 5.4$ and with $7 \mu \mathrm{mol} /$ liter albumin, there was 6 -fold increase in activity of urine amylase over the control, but at $\mathrm{pH} 6.0$, the increase was 2-fold. On the other hand Aw (1974) used radioactive starch, and reported that the $\mathrm{pH}$ of maximum activity was 7.0. In the present study, in urine, the mean of the group of $\mathrm{pH} 6$ or under was higher than that of the group of $\mathrm{pH} 7$ or over, although the difference is not significant.

Some investigators (Ceska et al., 1969; Van Riet and Hoeke, 1968) reported that there seemed to be no correlation between amylase activity and age or sex. In the present study, however, it seems to increase with the age. Sex difference was not indicated.

The log overall urine amylase activity in the final sample revealed unimodal distribution. However, if antilogarithm is taken there is a second small peak in the higher range. If a genetic variant is included, it may consist the second peak. Differences of enzyme activities among different genotypes were reported in acid phosphatase (Spencer et al., 1964; Harris, 1966; Eze et al., 1974; Pihar, 1975) glutamic pyruvic transaminase (Chen et al., 1972) and adenylate kinase (Modiano et al., 1970), but there is no report with respect to amylase. In the present subjects no variant was found by electrophoresis, but a possibility exists that the second peak may represent a thus far unknown variant which can not be demonstrated by the present electrophoretic method. In $3 \mathrm{MZ}$ twin pairs both twins indicated high urine amylase activity (800-1,000 Somogyi unit), and this finding supports the above hypothesis. In plasma amylase activity such second peak was not indicated, and this result might be due to small sample size.

As to the rates of Amy 1 or Amy 2 in plasma and urine it is well known that pancreatic isozyme is considerably more rapidly cleared by the kidney (Levitt et al., 1969; Duane et al., 1971, 1972). In serum, activity of pancreatic isozyme comprised less than half the total activity, 26.7 to $49.1 \%$, according to the Fridhandler et al. (1972). The rate was $46.5 \pm 6.4 \%$ according to Kamaryt (1969) and between $26.7 \%$ and 56.0\% according to Berk and Fridhandler (1975). Ojala and Harmoinen (1975) reported a similar finding with the ratio of pancreatic to salivary amylase activities in 49 healthy adults between 0.5 and 2.45 in serum and between 1.22 and 5.88 in urine. The present result is in accordance with the above previous findings.

It has been reported that the rates of isozyme and overall activity change in 
pathological conditions (Berk and Fridhander, 1975; Flick et al., 1970; Saxon et al., 1957; McCorkle and Goldman, 1942). In the present study subjects are normal and no significant correlation was found between $\operatorname{Sin}^{-1} \sqrt{\frac{\mathrm{P}}{\mathrm{S}+\mathrm{P}}}$ and $\log$ overall enzyme activity, either in plasma $(r=-0.3220, \mathrm{~N}=36)$ or in urine of the final sample $\mathrm{r}=0.2351$, $\mathrm{N}=54$ ).

It is generally assumed that greater similarity of $\mathrm{MZ}$ twins than $\mathrm{DZ}$ twins is an evidence for genetic contribution of a given trait. With respect to enzyme activity and protein concentration in the blood, a greater similarity of $\mathrm{MZ}$ twins than $\mathrm{DZ}$ twins has been reported in cholinesterase (Wetstone et al., 1965, Hosenfeld and Drössler, 1970), ceruloplasmin (Hosenfeld and Schröter, 1970), alkaline phosphatase (Hosenfeld and Schröter, 1970), lactate dehydrogenase, malate dehydrogenase, glutamic-pyrumic transaminase, glutamic-oxalacetic transaminase (Schloot et al., 1966), glucose-6-phosphate dehydrogenase in both males and females (Brewer, 1967), serum immuno-globulin (Kalff and Hijmans, 1969) and serum Ig E (Bazaral et al., 1974). On the contrary, a greater similarity of $D Z$ twins rather than $M Z$ twins has been reported in cholinesterase (Simpson and Kalow, 1963; Schloot et al., 1966), glucose-6-phosphate dehydrogenase in males (Beiguelman et al., 1970) and immunoglobulin (Carbonara et al., 1970). The different results among different investigators may be due to sampling error, age and sex difference or small number of twin pairs. In the present study urine amylase indicated a significant and higher correlation in $\mathrm{MZ}$ twins than in $\mathrm{DZ}$ twins as to overall activity, but not in the rate of isozyme activity. In plasma, on the other hand, correlations of $\mathrm{MZ}$ twins were significant and higher than those of $D Z$ twins in all respects, though $z$ test indicated a difference between $\mathrm{MZ}$ and $\mathrm{DZ}$ intraclass correlations only in overall amylase activity. It is concluded that overall amylase activity of both urine and plasma is at least genetically controlled. From family data heritability of overall plasma amylase activity is estimated between 0.4408 and 0.5298 .

Acknowledgement. I wish to make gateful acknowledgement to Prof. E. Inouye, Institute of Brain Research, University of Tokyo, for his valuable suggestions and discussions, and revision of my manuscript. I am deeply indebted to Prof. Z. Ogita, Research Institute for Wakan-Yaku, University of Toyama, for his support and encouragement. I also wish to thank Dr. A. Asaka, Institute of Brain Research, University of Tokyo, for the computer analysis of the data.

\section{REFERENCES}

Aw, S.E. 1966. A separation of urinary isoamylases on cellulose acetate. Nature 209: 298-300.

Aw, S.E. 1974. The radiometric assay of $\alpha$-amylase activity. Clin. Chim. Acta 56: 291-295.

Bazaral, M.H., Orgel, A., and Hamburger, R.N. 1974. Genetics of Ig E and allergy: serum Ig E levels in twins. J. Allergy Clin. Immunol. 54/5: 288-304.

Beiguelman, B., Colli-Inglez, G., and Bonder-Itskan, S. 1970. Glucose-6-phosphate dehydrogenase activity among caucasoid twins. Human Herd. 20: 535-539.

Berk, J.E., Hayashi, S., Searcy, R.L., et al. 1966. Differentiation of parotid and pancreatic amylase in human serum. Am. J. Dis. 11: 695-701. 
Berk, J.E. and Fridhandler, L. 1975. Clinical application of amylase isoenzyme analysis. Am. J. Gastroentrol. 63/6: 457-463.

Bernfeld, P. 1955. Enzymes of carbohydrate metabolism amylases, $\alpha$ and $\beta$. Methods in enzymology I (S.P. Colowick and N.O. Kaplan, eds.), Academic Press inc., publishers, New York, p. 149.

Brewer, G.J. 1967. Inheritance of quantitative expression of erythrocyte glucose-6-phosphate dehydrogenase activity in the negro-A twin study. Biochem. Genet. 1: 41-53.

Carbonara, A.O., Ceppellini, R., Yount, W., Ianducci, S. 1970. The serum Ig level in human twins. Acta Genet. Med. Gemellol. 19: 238.

Ceska, M., Brown, B., and Birath, K. 1969. Ranges of $\alpha$-amylase methods. Clin. Chim. Acta 26: 445-453.

Chen, Shi-Han, Giblett, E.R., Anderson, J.E., and Fossum, B.L.G. 1972. Genetics of glutamicpyruvic transaminase: its inheritance, common and rare variants, population distribution, and differences in catalytic activity. Ann. Hum. Genet., Lond 35: 401-409.

Duane, W.C., Frerichs, R., and Levitt, M.D. 1971. Distribution, turnover, and mechanism of renal excretion of amylase in the baboon. J. Clin. Invest. 50: 156-165.

Duane, W.C., Frerichs, R., and Levitt, M.D. 1972. Simultaneous study of the metabolic turnover and renal excretion of salivary amylase ${ }^{125} \mathrm{I}$ and pancreatic amylase ${ }^{131} \mathrm{I}$ in the baboon. J. Clin. Invest. 51: 1504-1513.

Eze, L.C., Tweedie, M.C.K., Bullen, M.F., Wren, P.J.J., and Evans, D.A.P. 1974. Quantitative genetics of human red cell acid phosphatase. Ann. Hum. Genet., Lond. 37: 333-340.

Flick, A.L., Bark, C.J., and Harrell, J.H. 1970. Serum amylase values by the caraway method in hospitalized patients and normal controls. Am. J. Clin. Path. 53: 458-461.

Fridhandler, L., Berk, J.E., and Ueda, M. 1972. Isolation and measurement of pancreatic amylase in human serum and urine. Clin. Chem. 15/12: 1493-1497.

Götz, H., Wüst, H., und Raies, F. 1968. Agarelektrophoretische studien zur frage von isoenzymen der amylase. Clin. Chim. Acta 19: 235-243.

Hall, F.F., Ratliff, C.R., Hayakawa, T., Culp, T.W. and Hightower, N.C. 1970. Substrate differentiation of human pancreatic and salivary alpha-amylases. Am. J. Dig. Dis. 15/11: 10311038.

Harris, H. 1966. Enzyme polymorphisms in man. Pro. Royal Soci., Lond. 164: 298-310.

Hosenfeld, D. and Schröter, E. 1970. Concerning the question of individual constancy and individual specificity of three serum enzyme activities (Serum cholinesterase EC 3.1.1.8, ceruolplasmin EC 1.10.3.2. and alkaline phosphatase EC 3.1.3.1.). Humangenetic 9: 38-42.

Hosenfeld, D., Drössler, E. 1970. Three serum enzymes in twins. Acta Genet. Med. Gemellol. 19: 122-126.

Inouye, E. 1956. A review on the zygosity diagnosis. Jap. J. Human Genet. 1: 24-31.

Inouye, E. 1962. Zygosity diagnosis of twins of the Japanese by essen-möller's formula. Studies on twins (Fujita, K. ed.), Nihon-Gakujutsu-Shinkikai, Tokyo (in Japanese) III: 1-13.

Irie, A., Hunaki, M., Bando, K., and Kawai, K. 1972. Determination of amylase activity in serum and urine using blue starch substrate. Clin. Chim. Acta 42: 63-66.

Kalff, M.W. and Hijmans, W. 1969. Serum immunoglobulin levels in twins. Clin. Exp. Immunol. 5: 469-477.

Kamarýt, J. and Laxová, R. 1965. Amylase heterogeneity. Humangenetik 1: 579-586.

Kamarýt, J. and Laxová, R. 1966. Amylase heterogeneity variants in man. Humangenetik 3: $41-45$.

Kamarýt, Von J. 1969. Nieren-clearance der isoamylasen bein menschen. Z. Klin. Chem. u. Klin. Biochem. 7: 51-52.

Kamarýt, J., Adámek, R., and Vrba, M. 1971. Possible linkage between uncoiler chromosome un 
1 and amylase polymorphism amy 2 loci. Humangenetik 11: 213-220.

Levitt, M.D., Rapoport, M., and Cooperband, S.R. 1969. The renal clearance of amylase in renal insufficiency, acute pancreatitis, and macroamylasemia. Ann. Internal. Med. 71/5: 919-925.

McCorkle, H. and Goldman, L. 1942. The clinical significance of the serum amylase test in the diagnosis of acute pancreatitis. Surg. Gynec. Obstet. 74: 439-445.

Merritt, A.D., Rivas, M.L., and Ward, J.C. 1972. Human amylase loci: evidence for close linkage. Nature Lond. 239 : 243-244.

Merritt, A.D., Rivas, M.L., Bixler, D., and Newell, R. 1973. Salivary and pancreatic amylase: electrophoretic characterizations and genetic studies. Am. J. Genet. 25: 510-522.

Modiano, G., Scozzari, R., Gigliani, F., Santolamazza, C., Spennati, G.F., and Saini, P. 1970. Enzyme activity in two red cell adenylate kinase phenotypes. Am. J. Human Genet. 22: 292-297.

Nørby, S. 1964. Electrophoretic non-identity of human salivary and pancreatic amylases. Exp. Cell Res. 36: 663-702.

Muss, J. and Vnenchak, J.M. 1964. Isozymes of salivary amylase. Nature 204: 293.

O'Donnell, M.D. and McGreeney, K.F. 1974. Activation of $\alpha$-amylase by protein and detergents. Enzyme 18: 356-367.

Ojala, K. and Harmoinen, A. 1975. Determination of amylase activity and amylase isoenzymes in serum and urine using a solid phase blue starch substrate. Scand. J. Clin. Lab. Invest. 35; $163-169$

Pihar, O. 1975. Red blood cell acid phosphatase: Ambiguity in phenotype and activity estimations in the proof of the "Single Allele" states. Humangenetik. 27: 235-240.

Rao, C.R. 1952. Advanced statistical methods in biometric research. John Wiley and Sons, Inc. New York, p. 86.

Reif, A.E. and Nabseth, D.C. 1962. Serum amylase determination by Somogyi's amyloclastic method with use of a photometric end-point. Clin. Chem. 8: 113-129.

Saxon, E.I., Hinkley, W.C., Vogel, W.C., and Zieve, L. 1957. Comparative value of serum and urinary amylase in the diagnosis of acute pancreatitis. Arch. Inter. Med. 99: 607-621.

Schloot, W., Murken, J.D., und Goedde, H.W. 1966. Vergleich der aktivitäten verschiedener serum enzyme bei zwillingen. Humangenetik. 2: 36-41.

Searcy, R.L., Ujihira, I., Hayashi, S., and Berk, J.E. 1964. An intrinsic disparity between amyloclastic and saccharogenic estimations of human serum isoamylase activities. Clin. Chim. Acta 9: 505-508.

Simpson, N.E. and Kalow, W. 1963. Serum cholinesterase levels in families and twins. Am. J. Hum. Genet. 15: 280-287.

Spencer, N., Hopkinson, D.A., Harris, H. 1964. Quantitative differences and gene dosage in the human red cell acid phosphatase polymorphism. Nature 201: 299-300.

Ujihira, I., Searcy, R.L., Berk, J.E. and Hayashi, S. 1965. A saccharogenic method for estimating electrophoretic and chromatographic distribution of human serum amylase. Clin. Chem.11/2: $97-112$.

Vaciková, A. and Blochová, L. 1969. Isoamylases in blood donors. Humangenetik 8: 162-164.

Van Riet, H.G. and Hoeke, J.O.O. 1968. Amylase and lipase values in normal subjects. Clin. Chim. Acta 19: 459-467.

Walker, G.J. and Hope, P.M. 1963. The action of some $\alpha$-amylases on starch granules. Biochem. J. 86: $452-462$.

Wetstone, H.J., Honeyman, M.S., and McComb, R.B. 1965. Genetic control of the quantitative activity of a serum enzyme in man. JAMA 192/11: 1007-1009.

Wolf, R.O. and Taylor, L.L. 1967. Isoamylases of human parotid saliva. Nature 213: 1128-1129.

Wolf, R.O., Taylor, L.L., Niswander, J.D., and Schwartz, J.T. 1971. The heritability of human salivary isoamylases. Archs. Oral. Biol. 16: 1357-1359. 